\title{
MODUS OPERANDI YANG MENJADIKAN PERBANKAN SEBAGAI SASARAN SUATU KEJAHATAN ${ }^{1}$
}

\author{
Oleh: \\ I Gusti Ngurah Krisnadi Yudiantara²
}

\begin{abstract}
Transnational crime related to financial, mostly done through the banking sector. The banking sector is one of the most widely used mode by the perpetrators of money laundering. It certainly can not be released with the development and progress of science and technology, especially in the field of communications that impact the financial system, including the integration of the banking system that offers traffic mekanmisme funds between countries which can be done in a very short time.
\end{abstract}

\section{Keywords: Transnational crime, The banking sector, The financial system Integration}

\begin{abstract}
Abstrak
Kejahatan transnasional yang berhubungan dengan finansial, banyak dilakukan melalui sektor perbankan. Sektor perbankan merupakan salah satu modus yang paling banyak dimanfaatkan oleh pelaku tindak pidana pencucian uang. Hal ini tentunya tidak dapat dilepaskan dengan perkembangan serta kemajuan ilmu pengetahuan dan teknologi khususnya di bidang komunikasi yang berdampak pula pada terintegerasinya sistem keuangan termasuk sistem perbankan yang menawarkan mekanisme lalu lintas dana antar negara yang dapat dilakukan dalam waktu yang sangat singkat.
\end{abstract}

\section{Kata kunci: Kejahatan transnasional, Sektor perbankan, Terintegrasinya sistem keuangan}

\section{PENDAHULUAN}

Kemajuan ilmu pengetahuan, teknologi informasi dan komunikasi, telah menunjukkan fenomena globalisasi, yang dimana telah memberikan manfaat positif untuk mendorong semakin mudahnya perpindahan orang, barang dan jasa dari suatu negara ke negara lain. Di sisi lain, fenomena globalisasi telah berperan merekonstruksikan modus operandi kejahatan transnational yang cukup kompleks. ${ }^{3}$

3 Wouter H. Muller, Christian H. Kalin, John G. Goldworth, 2007, Anti-Money Laundering International Law and Practice. West Sussex, England, hlm. 3.

1 Artikel ini merupakan penelitian/karya ilmiah mahasiswa pada Program Studi Magister (S2) Ilmu Hukum Program Pascasarjana Universitas Udayana dan mengucapkan terima kasih kepada orang tua saya yang telah membimbing serta memberi masukan kepada saya selama ini.

2 Krisnadi yudiantara adalah mahasiswa magister ilmu hukum Universitas Udayana, Denpasar, Bali, email: krisnadiyudiantara@rocketmail.com 
Perkembangan global telah mengubah karakteristik kejahatan yang semula dalam lingkup domestik telah bergeser menjadi kejahatan lintas negara atau kejahatan transnasional. Kejahatan transnasional (transnational crime) ini merupakan suatu konsep yang baru diperkenalkan tahun 90-andalampertemuan PBBtentang the prevention of crime and the treatment of offender. Pada tahun 1995, PBB mengidentifikasi 18 jenis kejahatan transnasional yaitu money laundering, terrorism, theft of art and cultural objects, theft of intellectual property, illicit arms trafficking, aircraft hijacking, sea piracy, insurance fraud, computer crime, environmental crime, trafficking in persons, trade in human body parts, illicit drug trafficking, fraudulent bankruptcy, infiltration of legal business, corruption and bribery of public or party officials.

PBB telah menyetujui $U N$ Convention Against Transnational Organized Crime (UNCATOC) yang lebih dikenal dengan sebutan Palermo Convention pada plenary meeting ke-62 tanggal 15 November 2000. Konvensi ini menghasilkan 4 (empat) protocol yaitu : ${ }^{4}$

1) United Nations Convention againstTransnationalOrganized Crime;

2) Protocol against the Smuggling of Migrants by Land Air and Sea, supplementing the United

4 Bucy, Pamela H White Collor Crime : Cases an Materials, St. Paul, Minn West Publishing Co. 1992
Nations Convention against

Transnational

Organized

Crime;

3) Protocol to Prevent, Suppress and Punish Trafficking in Persons, Especially Women and Children, supplementing the United Nations Convention against TransnationalOrganized Crime; dan

4) Protocol against the Illicit Manufacturing of and Trafficking in Firearms, Their Parts and Components and Ammunition, supplementing United Nations Convention against TransnationalOrganized Crime. $^{5}$

Kejahatan transnasional yang berhubungan dengan finansial, banyak digunakan melalui sektor perbankan. Sektor perbankan ini merupakan salah satu modus yang paling banyak dipergunakan oleh pelaku tindak pidana pencucian uang. Hal ini tentunya tidak dapat dilepaskan dengan perkembangan serta kemajuan ilmu pengetahuan dan teknologi khususnya di bidang komunikasi yang berdampak pula pada integrasi sistem keuangan termasuk sistem perbankan

5 Substansi UNCATOC meliputi: 1) Definisi dan terminologi standar, 2) Persyaratan agar setiap negara memiliki specific crime, 3) Langkahlangkah khusus untuk memonitor korupsi, money laundering, dsb, 4) Perampasan hasil kejahatan (proceeds of crime), 4) Kerjasama internasional yang mencakup antara lain ekstradisi, mutual legal assistance, penyelidikan/penyidikan dan bentuk lainnya, 5) Pelatihan dan penelitian, 6) Langkah Pencegahan, 7) Ratifikasi. 
yang menawarkan mekanisme lalu lintas dana antar negara yang dapat dilakukan dalam waktu yang sangat singkat.

Sektor perbankan yang memiliki kedudukan strategis sebagai lembaga intermediasi dan menunjang sistem pembayaran merupakan faktor yang sangat menentukan, karena industri perbankan merupakan salah satu komponen yang sangat penting dalam perekonomian nasional untuk menjaga keseimbangan kemajuan dan kesatuan ekonomi nasional. Stabilitas industri perbankan, sangat mempengaruhi sektor perekonomian secara menyeluruh.

Perkembangan ekonominasional di masa ini menunjukkan arah yang semakin menyatu dengan ekonomi regional dan internasional yang dapat menunjang dan sekaligus dapat berdampak kurang menguntungkan. Sementara itu perkembangan perekonomian nasional senantiasa bergerak cepat dengan tantangan yang semakin kompleks, oleh karena itu diperlukan berbagai penyesuaian kebijakan di bidang ekonomi termasuk sektor perbankan sehingga diharapkan akan dapat memperbaiki dan memperkokoh perekonomian nasional. Terintegerasinya sistem keuangan termasuk sistem perbankan yang menawarkan mekanisme lalu lintas dana antarnegara, di samping mempunyai dampak positif, juga membawa ekses negatif bagi kehidupan masyarakat, yaitu dengan semakin meningkatnya tindak pidana yang berskala nasional maupun internasional, dengan memanfaatkan sistem keuangan termasuk sistem perbankan untuk menyembunyikan ataumengaburkanasal-usulhasil tindak pidana. Di sisi lain, kemajuan sektor perbankan ternyata banyak digunakan untuk mengaburkan hasil kejahatan, karena jasa lembaga keuangan perbankan banyak dimanfaatkan untuk melakukan pencucian uang (money laundering) dengan pemanfaatan transaksi derivatif yakni melalui transfer-transfer internasional yang efektif.

Penelitian-penelitian sebelumnya yang mendukung Orisinalitas dari penelitian ini adalah pertama oleh Iwan Kurniawan dari jurnal ilmu hukum volume 3 nomer 1 tahun 2013 berjudul Perkembangan Tindak pidana Pencucian Uang (Money laundering) dan Dampaknya Terhadap Sektor Ekonomi dan Bisnis. Kedua oleh Elisabeth Y Metekohy dan Ida Nurhayati dari Jurnal Ekonomi dan Bisnis volume 11 nomor 1 Juni 2012 berjudul Efektifitas Prinsip Mengenal Nasabah Pada Bank Sebagai Salah Satu Upaya Mencegah Tindak Pidana Pencucian Uang. Dari kedua penelitian sebelumnya yang menjadi perbedaan adalah penelitian ini menganalisis dalam pemecahan modus operandi yang menjadikan perbankan sebagai sasaran suatu kejahatan.

Tujuan dari penelitian ini adalah untuk menganalisis dan 
mengidentifikasi ada tidaknya indikasi pidana pencucian uang dan tindak pidana lainnya dalam perbankan serta mengidentifikasi UndangUndang nomor 8 tahun 2010 tentang pencegahan dan pemberantasan tindak pidana pencucian uang dalam PPATK.

\section{METODE PENELITIAN}

Dalam setiap penelitian hendaknya memerlukan suatu metode agar suatu penelitian tersebut dapat dipertanggungjawabkan sebagaimana mestinya. Dimana jenis penelitian yang digunakan penulis untuk pembuatan jurnal ini, menggunakan jenis penelitian hukum normatif. Menurut Abdulkadir Muhammad penelitian hukum normatif ialah penelitian hukum yang didasari oleh hukum tertulis dari berbagai aspek, yaitu aspek teori, sejarah, filosofi, perbandingan, struktur dan komposisi, lingkup dan materi, konsistensi, penjelasan umum dan pasal dari pasal, formalitas dan mengikatnya, tetapi tidak mendasari aspek terapan atas implementasinya, maka penelitian hukum normatif sering juga disebut " penelitian hukum dogmatik" atau penelitian hukum teoritis (dogmatic or theoretical law research) ${ }^{6}$

Dalam penelitian ini jenis pendekatan terhadap permasalahan dalam penelitian ini akan dilakukan

6 Abdulkadir Muhamad, 2004, Hukum dan Penelitian Hukum, Bandung: Citra Aditya Bakti, hlm. 101. dengan 4 (empat) cara pendekatan, yaitu pendekatan perundang-undangan (statue approach), pendekatan analisis konsep hukum (analytical and conceptual approach), dan pendekatan perbandingan hukum (comparative approach). Dalam pendekatan perundang-undangan dilakukan pendekatan pada UU 8 Tahun 2010 tentang pencegahan dan pemberantasan tindak pidana pencucian uang, PPATK berkewajiban untuk melakukan analisis LTKM ini untuk mengidentifikasi ada tidaknya indikasi pidana pencucian uang dan tindak pidana lainnya. ${ }^{7}$ Pendekatan analisis konsep hukum ini dilakukan untuk menganalisis teori-teori hukum maupun konsep hukum yang berkaitan dengan penelitian terhadap modus operandi tindak pidana yang menjadikan perbankan sebagai sasaran sarana kejahatan, serta pendekatan perbandingan hukum ini mengacu pada perbandingan UU 8 Tahun 2010 terhadap undang-undang yang ada kaitannya terhadap pencucian uang agar kita mengetahui apakah di dalam undang-undang tersebut adanya norma kosong dan kekaburan norma.

III. HASIL DAN PEMBAHASAN

3.1 Pemanfaatan Jasa Perbankan Sebagai Sarana Untuk Melakukan Tindak Pidana Pencucian Uang

Strategi pencegahan dan

7 Undang-undang Nomor 8 Tahun 2010 tentang Pencegahan dan Pemberantasan Tindak Pidana Pencucian Uang. 
penanggulangan tindak pidana pencucian uang tidak dapat dilepaskan dengan karakteristik tindak pidana pencucian uang sebagai salah satu mata rantai kejahatan. Dalam dekade terakhirini,permasalahantindakpidana pencucian uang sudah berkembang dengan berbagai aspek permasalahan yang semakin kompleks. Kemajuan teknologi informasi telah berdampak pula terhadap tindak pidana pencucian uang yang tidak lagi terbatas dalam suatu wilayah negara tertentu, akan tetapi melintasi batas-batas yurisdiksi, dan menggunakan modus yang semakin bervariasi, memanfaatkan lembaga di luar sistem keuangan. Sektor perbankan merupakan salah satu modus yang paling banyak dimanfaatkan olehpelakutindakpidana pencucian uang. ${ }^{8}$ Hal ini tentunya tidak dapat lagi dilepaskan dengan perkembangan serta kemajuan ilmu pengetahuan dan teknologi khususnya di bidang komunikasi yang berdampak pada terintegerasinya sistem keuangan termasuk sistem perbankan yang menawarkan mekanisme lalu lintas dana antar negara yang dapat dilakukan dalam waktu yang benar-benar sangat singkat.

Sektor perbankan yang memiliki posisi strategis sebagai lembaga intermediasi dan penunjang sistem pembayaran merupakan faktor yang sangat menentukan, karena industri perbankan merupakan salah satu komponen yang sangat penting

8 Media Hukum Penanganan Tindak Pidana Pencucian Uang vol. 2 No. 10-22 Juli 2004. dalam perekonomian nasional demi menjaga keseimbangan kemajuan dan kesatuan ekonomi nasional. Stabilitas industri perbankan, sangat mempengaruhi sektor perekonomian secara keseluruhan.

Perkembangan ekonomi nasional saatinimenunjukkanarahyangsemakin menyatu dengan ekonomi regional dan internasional yang dapat menunjang dan sekaligus dapat berdampak sangat kurang menguntungkan. Sementara itu perkembangan perekonomian nasional senantiasa bergerak cepat dengan tantangan yang semakin kompleks, oleh karena itu diperlukan berbagai penyesuaian kebijakan di bidang ekonomi termasuk sektor perbankan sehingga diharapkan akan dapat memperbaiki dan memperkuat perekonomian nasional.

Terintegerasinya sistem keuangan termasuk sistem perbankan yang menawarkan mekanisme lalu lintas dana antarnegara, di samping mempunyai dampak positif, juga membawa dampak negatif bagi kehidupan masyarakat, yaitu dengan semakin meningkatnya tindak pidana yang berskala nasional maupun internasional, dengan memanfaatkan sistem keuangan termasuk sistem perbankan untuk menyembunyikan atau mengaburkan asal-usul hasil tindak pidana tersebut. ${ }^{9}$

Secara langsung pencucian uang tidak merugikan orang tertentu atau

9 Sutan Remy Sjahdeini, 2005, Pencucian Uang: Pengertian, Sejarah, Faktor Penyebab, dan Dampaknya Bagi Masyarakat, Jurnal Hukum Bisnis Vol. 22-No.3, hlm. 5 
perusahaan tertentu. Secarasepintaslalu pencucian uang tidak ada korbannya. Billy Steel pernah mengemukakan bahwa money laundering; "It Seem to be a victimless crime". ${ }^{10}$ Tetapi di balik semuanya, dalam skala mikro sebenarnya pencucian uang berdampak pada lembaga penyediaan jasa keuangan, karena lembaga penyedia jasa keuangan tersebut dapat terjerumus ke dalam bahaya likuiditas dan kelangsungan hidup bisnisnya. Sisi lain dalam skala makro pencucian uang dapat menciptakan instabilitas sistem keuangan, distorsi ekonomi kemungkinan terganggunya kontrol jumlah uang yang beredar, dan dapat menyebabkan turunnya stabilitas pemerintahan.

Dalam perkembangannya, tindak pidana pencucian uang semakin kompleks, melintasi batas-batas yurisdiksi suatu negara (borderless crime), indikasi pencucian uang sebagai kejahatan terorganisasi (organized crime) serta modus yang semakin variatif, dengan memanfaatkan lembaga di luar sistem keuangan. Untuk mengantisipasi hal itu, Financial Action Task Force (FATF) on Money Laundering telah mengeluarkan standar internasional yang menjadi ukuran bagi setiap negara dalam pencegahan dan pemberantasan tindak pidana Pencucian Uang dan tindak pidana pendanaan terorisme yang dikenal dengan Revised 40

10 Billy Steel, Money laundering - What is Money Laundering http;/www.laundryman. u-net.com.
Recommendations dan 9 Special Recommendations (Revised 40+9) FATF, antara lain mengenai perluasan Pihak Pelapor (reporting parties) yang mencakup pedagang permata dan perhiasan/logam mulia dan pedagang kendaraan bermotor, karena diyakini mencegah dan memberantas tindak pidana Pencucian Uang perlu dilakukan kerja sama regional dan internasional melalui forum bilateral atau multilateral agar intensitas tindak pidana yang menghasilkan atau melibatkan harta kekayaan yang jumlahnya besar dapat diminimalisasi.

\subsection{Peran PPAT (Pusat Pelaporan Analisis Transaksi Keuangan) Dalam Pencegahan Dan Penanggulangan Tindak Pidana Pencucian Uang (TPPU)}

Pemberantasan kejahatan secara represif, dalam paradigma lama menekankan pada Follow the Suspect lebihmenitikberatkan pada pengejaran para pelaku kejahatan. Berbeda halnya dengan paradigma baru yang lebih menekankan untuk mengejar uang atau Follow the Money atau berupaya melacak harta kekayaan yang berasal dari kejahatan, yang kemudian direkonstruksi dari mana kekayaan itu dan tindak pidana apa yang melahirkan kekayaan tersebut. Pendekatan ini lebih mudah dibandingkan dengan pendekatan konvensional karena pencucian uang adalah mata rantai paling lemah dari suatu kejahatan. 
Mengejar pelaku kejahatan relatif lebih sulit, dibandingkan dengan menelusuri hasil kejahatan. Pemberantasan tindak pidana dengan paradigma baru mengisyaratkan bahwa sasaran yang hendak dituju dalam pemberantasan tindak pidana yang represif adalah "lifeblood of the crime" serta menghilangkan motivasi orang melakukan tindak pidana. Dengan pendekatan konvensional biasanya yang terjerat adalah pelaku kelas bawah, dan tidak menyentuh aktor utamayangsesungguhnya. Rasionalitas konsep paradigma tersebut didasari dengan suatu argumen yang sederhana bahwa untuk memulai penyelidikan dan penyidikan tidak perlu dibuktikan terlebih dahulu tindak pidana asalnya, sehingga dalam proses penanganan tindak pidana pencucian uang ini mirip dengan tindak pidana penadahan. Di samping konsep pemikiran tersebut, dalam tindak pidana pencucian uang, kriminalisasi suatu perbuatan sebagai tindak pidana dilandasi dengan terpenuhinya syarat kriminalisasi pada umumnya yaitu: a. adanya korban; b. kriminalisasi bukan semata-mata ditujukan untuk pembalasan; c. harus berdasarkan asas ratio-principle; $\mathrm{d}$. adanya kesepakatan sosial (public support). Terkait tentang adanya korban berarti pencucian uang harus menimbulkan sesuatu yang buruk atau menimbulkan kerugian, setelah melalui perdebatan panjang disepakati bahwa pencucian uang itu tidak merugikan individu secara langsung tetapi berdampak pada munculnya kerugian keuangan nasional bahkan membahayakan keuangan global. Dengan demikian strategi pencegahan dan penanggulangan tindak pidana pencucian uang tidak dapat dilepaskan dengan karakteristik tindak pidana pencucian uang sebagai salah satu mata rantai kejahatan.

Dalam dasa warsa terakhir, permasalahan tindak pidana Pencucian Uang sudah berkembang dengan berbagai aspek permasalahan yang semakin kompleks. Kemajuan teknologi informasi telah berdampak pula terhadap tindak pidana pencucian uang yang tidak lagi terbatas dalam suatu wilayah negara tertentu, tetapi melintasi batas-batas yurisdiksi, dan menggunakan modus yang semakin bervariatif, memanfaatkan lembaga di luar sistem keuangan. Sektor perbankan merupakan salah satu modus yang paling banyak dimanfaatkan oleh pelaku tindak pidana pencucian uang. Hal ini tentunya tidak dapat dilepaskan dengan perkembangan serta kemajuan ilmu pengetahuan dan teknologi khususnya di bidang komunikasi yang berdampak pula pada terintegerasinya sistem keuangan termasuk sistem perbankan yang menawarkan mekanisme lalu lintas dana antar negara yang dapat dilakukan dalam waktu yang sangat singkat. ${ }^{11}$

11 Barda Nawawi Arief 2005. "Sistem Pemidanaan Dalam Ketentuan Umum Buku I RUU KUHP 2004" Bahan Sosialisasi Rancangan Undang-undang tentang KUHP 2004. Diselenggarakan oleh DepKum dan HAM, Jakarta tgl 23 - 24 Maret 2005 
Money laundering merupakan salah satu aspek perbuatan kriminal, sifat kriminalitas money laundering inilah berkaitan dengan latar belakang dari perolehan uang yang sifatnya gelap, haram atau kotor, lalu sejumlah uang kotor ini kemudian dikelola dengan aktivitas-aktivitas tertentu seperti dengan membentuk usaha, mentransfer atau mengkonversikannya ke bank atau valuta asing sebagai langkah untuk menghilangkan latar belakang dari dana kotor tersebut. Cara pemutihan atau pencucian uang dengan melalui serangkaian transaksi finansial yang rumit guna menyulitkan berbagai pihak untuk mengetahui asal-usul uang tersebut. Kebanyakan orang beranggapan transaksi derivatif merupakan cara yang paling disukai karena kerumitan nya dan daya jangkauannya menembus batas-batas yurisdiksi. Kerumitan inilah kemudian dimanfaatkan para pelaku money laundering guna melakukan tahap proses pencucian uang.

Secara langsung pencucian uang tidak merugikan orang tertentu atau perusahaan tertentu. Tampaknya secara sepintas lalu pencucian uang tidak ada korbannya. Billy Steel pernah mengemukakan bahwa money laundering; "It Seem to be a victimless crime”. Tetapi dibalik semuaitu, dalam skala mikro sebenarnya pencucian uang berdampak pada lembaga penyediaan jasa keuangan, karena lembaga penyedia jasa keuangan tersebut dapat terjerumus ke dalam bahaya likuiditas dan kelangsungan hidup bisnisnya. Sementara dalam skala makro pencucian uang dapat menciptakan instabilitas sistem keuangan, distorsi ekonomi kemungkinan terganggunya kontrol jumlah uang yang beredar, dan dapat menyebabkan turunnya stabilitas pemerintahan.

Dalam perkembangannya, tindak pidana Pencucian Uang semakin kompleks, melintasi batas-batas yurisdiksi suatu negara (borderless crime), indikasi pencucian uang sebagai kejahatan terorganisasi (organized crime) serta modus yang semakin variatif, dengan memanfaatkan lembaga di luar sistem keuangan. Untuk mengantisipasi hal itu, Financial Action Task Force (FATF) on Money Laundering telah mengeluarkan standar internasional yang menjadi ukuran bagi setiap negara dalam pencegahan dan pemberantasan tindak pidana Pencucian Uang dan tindak pidana pendanaan terorisme yang dikenal dengan Revised 40 Recommendations dan 9 Special Recommendations (Revised 40+9) FATF, antara lain mengenai perluasan Pihak Pelapor (reporting parties) yang mencakup pedagang permata dan perhiasan/logam mulia dan pedagang kendaraan bermotor, karena diyakini mencegah dan memberantas tindak pidana Pencucian Uang perlu dilakukan kerja sama regional dan internasional melalui forumbilateral atau multilateral agar intensitas tindak pidana yang menghasilkan atau melibatkan harta 
kekayaan yang jumlahnya besar dapat diminimalisasi. ${ }^{12}$

Sektor perbankan memiliki posisi strategis sebagai lembaga intermediasi dan penunjang sistem pembayaran merupakan faktor yang sangat menentukan, karena industri perbankan merupakan salah satu komponen yang sangat penting dalam perekonomian nasional demi menjaga keseimbangan kemajuan dan kesatuan ekonomi nasional. Stabilitas industri perbankan, sangat mempengaruhi sektor perekonomian secara keseluruhan. ${ }^{13}$

Perkembangan ekonominasional dewasa ini menunjukkan arah yang semakin menyatu dengan ekonomi regional dan internasional yang dapat menunjang dan sekaligus dapat berdampak kurang menguntungkan. Sementara itu perkembangan perekonomian nasional senantiasa bergerak cepat dengan tantangan yang semakin kompleks, oleh karena itu diperlukan berbagai penyesuaian kebijakan di bidang ekonomi termasuk sektor perbankan sehingga diharapkan akan dapat memperbaiki dan memperkokoh perekonomian nasional.

Terintegerasinya sistem keuangan termasuk sistem perbankan yang menawarkan mekanisme lalu

12 Yunus Husein, 2007, Bunga Rampai Anti Pencucian Uang, Bandung: Books Terrace \& Library.

13 LMM. Samosir, Tindak Pidana di Bidang Perbankan. 2000. Widya Iswara Luar Biasa, Jakarta. hlm. 45. lintas dana antarnegara, di samping mempunyai dampak positif, juga membawa ekses negatif bagi kehidupan masyarakat, yaitu dengan semakin meningkatnya tindak pidana yang berskala nasional maupun internasional, dengan memanfaatkan sistem keuangan termasuk sistem perbankan untuk menyembunyikan atau mengaburkan asal-usul hasil tindak pidana.

\section{KESIMPULAN}

1. Kemajuan ilmu pengetahuan dan teknologi informasi dan komunikasi, telah memunculkan fenomena globalisasi, yang di satu sisi memberikan manfaat positif karena, mendorong semakin mudahnya perpindahan orang, barang dan jasa dari suatu negara ke negara lain. Di sisi lain, fenomena globalisasi telah berperan merekonstruksikan modus operandi kejahatan transnasional yang cukup kompleks. Perkembangan global telah mengubah karakteristik kejahatan yang semula dalam lingkup domestik telah bergeser menjadi kejahatan lintas negara atau kejahatan transnasional.

2. Undang-undang Nomor 8 Tahun 2010 Tentang Pencegahan dan Pemberantasan Tindak Pidana Pencucian Uang, Pasal 3 telah memenuhi standar yang pada umumnya dipakai dalam kriminalisasi pencucian 
uang, yaitu meliputi: 1. A financial transaction (transaksi keuangan); 2. Proceed (hasilhasil kejahatan); 3. Unlawful activity (tindakan kejahatan); 4. Knowledge (mengetahui atau patut mengetahui); 5. Intent (maksud).

\section{DAFTAR PUSTAKA}

\section{Buku}

Abdulkadir Muhamad, 2004, Hukum dan Penelitian Hukum, Bandung: Citra Aditya Bakti.

Bucy, Pamela H White Collor Crime: Cases an Materials, St. Paul, Minn West Publishing Co. 1992

LMM. Samosir, Tindak Pidana di Bidang Perbankan. 2000. Widya Iswara Luar Biasa, Jakarta.

Substansi UNCATOC meliputi: 1) Definisi dan terminologi standar, 2) Persyaratan agar setiap negara memiliki specific crime, 3) Langkah-langkah khusus untuk memonitor korupsi, money laundering, dsb, 4) Perampasan hasil kejahatan (proceeds of crime), 4) Kerjasama internasional yang mencakup antara lain ekstradisi, mutual legal assistance, penyelidikan/ penyidikan dan bentuk lainnya, 5) Pelatihan dan penelitian, 6) Langkah Pencegahan, 7) Ratifikasi.

Wouter H. Muller, Christian H. Kalin, John G. Goldworth, 2007, Anti-
Money Laundering International Law and Practice. West Sussex, England.

Yunus Husein, 2007, Bunga Rampai Anti Pencucian Uang, Bandung: Books Terrace \& Library.

\section{Artikel}

Artikel ini merupakan penelitian/karya ilmiah mahasiswa pada Program Studi Magister (S2) Ilmu Hukum Program Pascasarjana Universitas Udayana dan mengucapkan terimakasih kepada orang tua saya yang telah membimbing serta memberi masukan kepada saya selama ini.

Barda Nawawi Arief 2005. "Sistem Pemidanaan Dalam Ketentuan Umum Buku I RUU KUHP 2004" Bahan Sosialisasi Rancangan Undang-undang tentang KUHP 2004. Diselenggarakan oleh DepKum dan HAM, Jakarta tgl 23 - 24 Maret 2005.

Krisnadi yudiantara adalah mahasiswa magister ilmu hukum Universitas Udayana, Denpasar, Bali, email: krisnadiyudiantara@roketmail. com

Media Hukum Penanganan Tindak Pidana Pencucian Uang vol. 2 No. 10-22 Juli 2004.

Sutan Remy Sjahdeini, 2005, Pencucian Uang: Pengertian, Sejarah, Faktor Penyebab, dan Dampaknya Bagi Masyarakat, Jurnal Hukum Bisnis Vol. 22No.3, h. 5 


\section{Peraturan Perundang-undangan}

1. Undang-undang Nomor. 15

Tahun 2002 tentang Tindak

Pidana Pencucian Uang.

2. Undang-undang Nomor. 25

Tahun 2003 tentang Tindak

Pidana Pencucian Uang.

3. Undang-undang Nomor. 8 Tahun

2010 tentang Pencegahan dan

Pemberantasan Tindak Pidana

Pencucian Uang.

4. Undang-undang Nomor 10

Tahun 1998 tentang Perbankan.

5. Undang-Undang No. 7 Tahun 1992 tentang Perbankan.

\section{Internet}

Billy Steel, Money laundering - What is Money Laundering http;/ www.laundryman.u-net.com, diakses tanggal 1 Januari 2017. 